\title{
Culture collection of freshwater microalgae from the Azores archipelago: resource for taxonomic and phycoprospecting research
}

\author{
Emanuel D. XAVIER ${ }^{a^{*}}$, Vitor GONÇALVES ${ }^{b}$, Alberto REIS ${ }^{c}$, \\ José M. N. AZEVEDO ${ }^{a}$ \& Ana I. NETO ${ }^{a}$
}

${ }^{a c}$ E3c - Centre for Ecology, Evolution and Environmental Changes/ Azorean

Biodiversity Group, Universidade dos Açores, Faculdade de Ciências e Tecnologia, Departamento de Biologia, 9500-321 Ponta Delgada, São Miguel, Azores, Portugal

${ }^{b}$ CIBIO - Centro de Investigação em Biodiversidade e Recursos Genéticos, InBIO Laboratório Associado, Pólo dos Açores, Universidade dos Açores, Faculdade de Ciências e Tecnologia, Departamento de Biologia da Universidade dos Açores, 9501-801 Ponta Delgada, Portugal ${ }^{c} L N E G$ - Laboratório Nacional de Energia e Geologia, I.P.,
Unidade de Bioenergia, Lisboa, Portugal

\begin{abstract}
Résumé - Collection de cultures de microalgues d'eau douce de l'archipel des Açores : ressource pour la recherche taxonomique et la phycoprospection. Ces dernières années, un grand intérêt a été porté sur le potentiel biotechnologique des microalgues, notamment du fait de leur rapide croissance et de l'identification de certaines substances synthétisées par ces organismes. L'isolation puis la culture in vitro d'espèces de microalgues natives sont très importantes pour les études taxonomiques et les études de conservation. Elles représentent les premières étapes des études de faisabilité pour des productions commerciales locales. Dans cette étude, 114 microalgues ont été isolées à partir d'échantillons prélevés dans 23 stations de l'île de São Miguel, Açores. Parmi celles-ci, 60 espèces ont été identifiées dont 39 Chlorophytes, 10 Ochrophytes, 6 Cyanophytes, 3 Charophytes, 1 Euglénozoaire et 1 Cryptophyte. Dix-huit de ces identifications d'espèces constituent de nouveaux enregistrements pour l'île de São Miguel.
\end{abstract}

Microalgues natives / Nouveaux reports / Isolement / Collection de cultures

\begin{abstract}
In recent years, much interest has been focused on the biotechnological potential of microalgae, mainly due to their rapid growth and the identification of several substances synthesized by these organisms. The isolation and in vitro cultivation of native microalgae species is very important for taxonomic and conservation studies and is the first step towards feasibility studies of local commercial productions. In this study 114 isolates of microalgae were obtained from samples collected in 23 locations of the island of São Miguel, Azores. From them, 60 species were identified comprising 39 Chlorophyta, 10 Ochrophyta, 6 Cyanophyta, 3 Charophyta, 1 Euglenozoa and 1 Cryptophyta. Eighteen of the species identified constitute new records for the Island of São Miguel.
\end{abstract}

Native microalgae / new records / isolation / culture collection

\footnotetext{
* Corresponding author: emanuel.d.xavier@uac.pt
} 